\title{
Kaistia terrae sp. nov., isolated from a wetland in Korea
}

\author{
Soo-Jin Kim, ${ }^{1}$ Hang-Yeon Weon, ${ }^{1}$ Yi-Seul Kim, ${ }^{1}$ Rangasamy Anandham, ${ }^{2}$ \\ Seung-Hee Yoo, ${ }^{1}$ In-Cheol Park ${ }^{1}$ and Soon-Wo Kwon ${ }^{1}$ \\ ${ }^{1}$ Korean Agricultural Culture Collection (KACC), National Agrobiodiversity Center, National \\ Academy of Agricultural Science, Rural Development Administration (RDA), Suwon 441-707, \\ Republic of Korea \\ ${ }^{2}$ Agricultural Microbiology, Department of Agricultural Microbiology, Agricultural College and \\ Research Institute, Madurai India
}

Correspondence

Soon-Wo Kwon

swkwon@rda.go.kr

\begin{abstract}
An ivory-coloured bacterium, designated strain $5 \mathrm{YN}^{-}-3^{\top}$, was isolated from a wetland, Yongneup, Korea. Cells of the strain were aerobic, Gram-stain-negative, non-motile and short rods. 16S rRNA gene sequence analysis demonstrated that strain $5 \mathrm{YN}^{-}-3^{\top}$ belongs to the order Rhizobiales of the class Alphaproteobacteria and is closely related to Kaistia soli 5 YN9-8 ${ }^{\top}$ (97.8\%), Kaistia granuli Ko04 ${ }^{\top}(97.6 \%)$ and Kaistia adipata Chj404 ${ }^{\top}(97.4 \%)$. Strain 5YN7-3 ${ }^{\top}$ showed DNA-DNA hybridization values of 28, 22 and $35 \%$ with $K$. granuli $\mathrm{KoO}^{\top}{ }^{\top}$, $K$. soli $5 \mathrm{YN} 9-8^{\top}$ and $K$. adipata $C h j 404^{\top}$, respectively. The major fatty acids were $\mathrm{C}_{18: 1} \omega 7 \mathrm{c}$ (51.2\%), $\mathrm{C}_{19: 0}$ cyclo $\omega 8 \mathrm{c}(25.0 \%), \mathrm{C}_{18: 0}(12.9 \%)$ and $\mathrm{C}_{16: 0}(10.8 \%)(>10 \%$ of total fatty acids). Ubiquinone-10 was the major isoprenoid quinone and the DNA $\mathrm{G}+\mathrm{C}$ content was $66.5 \mathrm{~mol} \%$. The phenotypic characteristics in combination with 16S rRNA gene sequence analysis and DNA-DNA hybridization data clearly define strain $5 \mathrm{YN}^{-}-3^{\top}$ as a novel species of the genus Kaistia, for which the name Kaistia terrae sp. nov. is proposed. The type strain is 5 YN7-3 $3^{\top}$ $\left(=\right.$ KACC $12910^{\top}=$ DSM $\left.21341^{\top}\right)$.
\end{abstract}

The genus Kaistia was described by Im et al. (2004) and contains three species at the time of writing, namely Kaistia adipata (Im et al., 2004), Kaistia granuli (Lee et al., 2007) and Kaistia soli (Weon et al., 2008b). Members of the genus Kaistia are characterized as non-motile, mesophilic, oxidase- and catalase-positive, rod- or coccus-shaped bacteria. Ubiquinone-10 (Q-10) is the major isoprenoid quinone and the major fatty acids are $\mathrm{C}_{18: 1} \omega 7 c$ and $\mathrm{C}_{19: 0} \omega 8$ c cyclo.

Yongneup $\left(38^{\circ} 12^{\prime} 53^{\prime \prime} \mathrm{N} 128^{\circ} 07^{\prime} 30^{\prime \prime} \mathrm{E}\right)$, the only high moor in Korea, is a wetland at 1200-1280 m above sea level. It is located around the top of Mount Daeam, Seohwa-myõn, Inje-gun, Kangwon-do, Korea. The peat layers are approximately $150 \mathrm{~cm}$ thick and were formed over 4000-5000 years. This area has a unique type of ecosystem in terms of weather, soil and vegetation. During the course of studies on the presence of cultivable bacterial communities in Yongneup wetland, a number of novel bacterial strains were isolated (Weon et al., 2008a, b; Kwon et al., 2008). A peat sample was serially diluted with $0.85 \%$ (w/v) $\mathrm{NaCl}$ and appropriate 10-fold dilutions were plated on R2A agar (Difco) (Reasoner \& Geldreich, 1985). The

The GenBank/EMBL/DDBJ accession number for the 16S rRNA gene sequence of strain 5 YN7 $^{-} 3^{\top}$ is EU723082. plates were incubated at $30{ }^{\circ} \mathrm{C}$ for 4 days. Strain $5 \mathrm{YN} 7-3^{\mathrm{T}}$ was one of the isolates that appeared on the R2A medium and could be distinguished in terms of ivory-coloured colonies and subjected to taxonomic investigation. In this study, we have characterized strain 5YN7-3 ${ }^{\mathrm{T}}$. Phenotypic, chemotaxonomic and phylogenetic analyses revealed that strain $5 Y N 7-3^{\mathrm{T}}$ was a member of the genus Kaistia. On the basis of the substantial evidence obtained from the polyphasic taxonomic studies, we propose $5 \mathrm{YN}^{-}-3^{\mathrm{T}}$ as the type strain of a novel species of the genus Kaistia, namely Kaistia terrae.

Cell morphology and motility were observed under a phase-contrast microscope (AXIO; ZEISS) and transmission electron microscope (912AB; LEO) after cultivation of strain $5 \mathrm{YN} 7-3^{\mathrm{T}}$ on $\mathrm{R} 2 \mathrm{~A}$ at $30{ }^{\circ} \mathrm{C}$ for 1 day. Gram staining, presence of catalase and oxidase activities, accumulation of poly- $\beta$-hydroxybutyrate and hydrolysis of casein, DNA and starch were determined as described by Smibert \& Krieg (1994). Hydrolysis of CM-cellulose $(0.1 \%, \mathrm{w} / \mathrm{v})$, chitin from crab shells $(1 \%, \mathrm{w} / \mathrm{v})$, pectin $(0.5 \%, \mathrm{w} / \mathrm{v})$ and tyrosine $(0.5 \%, \mathrm{w} / \mathrm{v})$ were also examined. Growth at different temperatures $(5,10,15,20,25,30,35$, 37,40 and $45^{\circ} \mathrm{C}$ ) and various $\mathrm{pH}$ (4.0-10.0 at intervals of $1.0 \mathrm{pH}$ units) were assessed after 7 days of incubation in R2A broth. Salt tolerance was tested in liquid R2A medium 
supplemented with $0-7 \% \mathrm{NaCl}(0,1,2,3,5$ and $7 \%$, w/v) after 7 days of incubation at $30{ }^{\circ} \mathrm{C}$. Carbon source utilization and some enzyme activities were tested by using the API 20NE, API ZYM and API ID 32 GN systems (bioMérieux) according to the manufacturer's instructions. Cells of strain 5YN7-3 $3^{\mathrm{T}}$ were aerobic, Gram-stain-negative, non-motile and short rods. Strain $5 \mathrm{YN} 7-3^{\mathrm{T}}$ was able to grow on R2A, nutrient agar (NA), tryptic soy agar (TSA) and MacConkey agar (Difco). Results of the phenotypic and physiological characterization are given in Table 1 and the species description.

Genomic DNA was isolated by the method of Ausubel et al. (1987), except that the lysates were extracted twice with chloroform to remove residual phenol. The $16 \mathrm{~S}$ rRNA gene was amplified by using the universal primers $\mathrm{fD} 1$ and $\mathrm{rP} 2$ (Weisburg et al., 1991), and sequenced as described by Kwon et al. (2003). Sequence similarity levels were calculated by the EzTaxon server (http://www.eztaxon. org/; Chun et al., 2007). Alignment of 16S rRNA gene sequences was performed with the CLUSTAL $\mathrm{W}$ program (Thompson et al., 1994). Phylogenetic analysis was performed using MEGA version 3.1 (Kumar et al., 2004). Distances using distance options according to the Kimura two-parameter model (Kimura, 1983) and clustering using the neighbour-joining method (Saitou \& Nei, 1987) and maximum-parsimony (Fitch, 1971) were determined using bootstrap values based on 1000 replicates (Felsenstein, 1985). The nearly complete $16 \mathrm{~S}$ rRNA gene sequence (1429 bp) was determined for strain $5 \mathrm{YN} 7-3^{\mathrm{T}}$. The $16 \mathrm{~S}$

Table 1. Phenotypic and chemotaxonomic characteristics that distinguish strain $5 \mathrm{YN} 7-3^{\top}$ from other species of the genus Kaistia

Strains: 1,5 YN7 $-3^{\mathrm{T}}$ (data from this study); 2, Kaistia adipata Chj404 ${ }^{\mathrm{T}} ; 3$, K. granuli Ko04 ${ }^{\mathrm{T}} ; 4$, K. soli 5YN9-8 ${ }^{\mathrm{T}}$. Data for columns $2-4$ from Weon et al. (2008b) except where indicated. All strains were positive for urease, aesculin hydrolysis, $\beta$-galactosidase, esterase (C4), leucine arylamidase, acid phosphatase, naphthol-AS-BI-phosphohydrolase, $\alpha$-glucosidase and $\beta$-glucosidase. All strains were negative for indole production, glucose fermentation, arginine dihydrolase, lipase (C14), valine arylamidase, cystine arylamidase, trypsin, $\alpha$-chymotrypsin, $\alpha$-galactosidase and $\beta$-glucuronidase. All strains assimilated D-glucose, L-arabinose, D-mannose, D-mannitol, $N$-acetylglucosamine, maltose, L-rhamnose, D-ribose, inositol, sucrose, salicin, melibiose, L-fucose and D-sorbitol. All strains assimilated lactic acid and potassium 2-ketogluconate weakly. None of the strains assimilated potassium gluconate, capric acid, adipic acid, trisodium citrate, phenylacetic acid, itaconic acid, suberic acid, sodium malonate, 3-hydroxybenzoic acid, L-serine, propionic acid, valeric acid, L-histidine or 4-hydroxybenzoic acid. For fatty acid analysis, cells of all strains were harvested after growth on $\mathrm{R} 2 \mathrm{~A}$ at $30{ }^{\circ} \mathrm{C}$ for 2 days. + , Positive; $(+)$ weakly positive; - , negative.

\begin{tabular}{|c|c|c|c|c|}
\hline Characteristic & 1 & 2 & 3 & 4 \\
\hline Nitrate reduction & - & + & + & - \\
\hline Growth at $37{ }^{\circ} \mathrm{C}$ & - & $+^{*}$ & $-{ }^{*}$ & + \\
\hline Growth on MacConkey agar ${ }^{\star}$ & + & + & + & - \\
\hline Starch hydrolysis & - & $+^{*}$ & $+^{*}$ & - \\
\hline Gelatin hydrolysis & - & + & - & - \\
\hline \multicolumn{5}{|l|}{ Assimilation of: } \\
\hline Malic acid & - & - & - & + \\
\hline Sodium acetate & - & $(+)$ & - & - \\
\hline L-Alanine & $(+)$ & $(+)$ & - & - \\
\hline Potassium 5-ketogluconate & $(+)$ & $(+)$ & + & - \\
\hline Glycogen & + & $(+)$ & - & $(+)$ \\
\hline 3-Hydroxybutyric acid & - & $(+)$ & - & - \\
\hline L-Proline & - & $(+)$ & - & - \\
\hline \multicolumn{5}{|l|}{ Enzymic activities } \\
\hline Alkaline phosphatase & + & - & + & - \\
\hline Esterase lipase (C8) & - & - & - & + \\
\hline$N$-Acetyl- $\beta$-glucosaminidase & - & - & - & + \\
\hline$\alpha$-Mannosidase & - & + & - & + \\
\hline$\alpha$-Fucosidase & - & - & - & + \\
\hline \multicolumn{5}{|l|}{ Fatty acids (\%) } \\
\hline 11-Methyl $\mathrm{C}_{18: 1} \omega 7 c$ & - & - & - & 4.2 \\
\hline iso- $\mathrm{C}_{11: 0} 3-\mathrm{OH}$ & - & 3.5 & - & 1.1 \\
\hline $\mathrm{C}_{16: 0}$ & 10.8 & 11.2 & 6.4 & 11.4 \\
\hline $\mathrm{C}_{18: 0}$ & 12.9 & 13.7 & 9.5 & 19.7 \\
\hline $\mathrm{C}_{18: 1} \omega 7 c$ & 51.2 & 52.7 & 55.7 & 46.8 \\
\hline $\mathrm{C}_{19: 0}$ cyclo $\omega 8 c$ & 25.0 & 18.9 & 28.4 & 16.7 \\
\hline DNA G $+\mathrm{C}$ content $(\mathrm{mol} \%)$ & 66.5 & 67.7 & 67.8 & 67.0 \\
\hline
\end{tabular}

${ }^{\star}$ Data from this study. 
rRNA gene sequence analysis revealed that strain $5 \mathrm{YN} 7-3^{\mathrm{T}}$ was most closely related to $K$. soli $5 \mathrm{YN} 9-8^{\mathrm{T}}(97.8 \%)$, K. granuli $\mathrm{Ko}^{\mathrm{T}}{ }^{\mathrm{T}}(97.6 \%)$ and K. adipata Chj $404^{\mathrm{T}}(97.4 \%)$. Strain 5 YN7 $73^{\mathrm{T}}$ showed less than $94 \% 16 \mathrm{~S}$ rRNA gene sequence similarity to the type strains of all recognized species of the order Rhizobiales of the class Alphaproteobacteria. The neighbour-joining tree (Fig. 1) showed that strain 5YN7-3 ${ }^{\mathrm{T}}$ formed a compact cluster with $K$. granuli $\mathrm{Ko}^{\mathrm{T}} 4^{\mathrm{T}}, K$. soli 5YN9- $8^{\mathrm{T}}$ and $K$. adipata Chj404 ${ }^{\mathrm{T}}$. The tree obtained using the maximum-parsimony method also showed that strain 5 YN7- $3^{\mathrm{T}}$ was a member of the genus Kaistia (Fig. 1).

Cellular fatty acid methyl esters were prepared for the bacteria grown in $\mathrm{R} 2 \mathrm{~A}$ medium for 2 days at $30^{\circ} \mathrm{C}$, and analysed using gas chromatography according to the instructions of the Microbial Identification System (MIDI). The predominant fatty acids of strain $5 \mathrm{YN} 7-3^{\mathrm{T}}$ were $\mathrm{C}_{18: 1} \omega 7 c(51.2 \%), \mathrm{C}_{19: 0} \omega 8 c$ cyclo $(25.0 \%), \mathrm{C}_{18: 0}(12.9 \%)$ and $\mathrm{C}_{16: 0}(10.8 \%)$ (Table 1$)$. Isoprenoid quinones were analysed by HPLC as described by Groth et al. (1996). Strain 5 YN7 $-3^{\mathrm{T}}$ had ubiquinone-10 as the predominant isoprenoid quinone. DNA $\mathrm{G}+\mathrm{C}$ contents $(\mathrm{mol} \%)$ were determined by HPLC analysis of deoxyribonucleosides as described by Mesbah et al. (1989), using a reverse-phased column (Supelcosil LC-18 S; Supelco). The DNA G+C content of strain $5 \mathrm{YN}^{-}-3^{\mathrm{T}}$ was $66.5 \mathrm{~mol} \%$. DNA-DNA hybridization tests were carried out using the filter hybridization method as described previously by Seldin \& Dubnau (1985). Probe labelling was conducted by using the non-radioactive DIG-High prime system (Roche). Further, the hybridized DNA was visualized using the DIG luminescent detection kit (Roche). DNA-DNA relatedness was quantified by using a densitometer (Bio-Rad). Strain 5YN7-3 ${ }^{\mathrm{T}}$ showed DNA-DNA hybridization values of 28,22 and $35 \%$ with K. granuli $\mathrm{Ko} 04^{\mathrm{T}}$, K. soli $5 \mathrm{YN} 9-8^{\mathrm{T}}$ and $K$. adipata $\mathrm{Chj} 404^{\mathrm{T}}$, respectively. These values are below the threshold value $(70 \%)$ suggested for species delineation (Wayne et al., 1987), indicating that strain 5YN7-3 $3^{\mathrm{T}}$ represents a novel species of the genus Kaistia.

Strain 5 YN7 $-3^{T}$ can be differentiated from $K$. adipata Chj $404^{\mathrm{T}}$ by the absence of nitrate reduction, growth at $37^{\circ} \mathrm{C}$, and starch and gelatin hydrolysis, the negative response for assimilation of sodium acetate, 3-hydroxybutyric acid and L-proline, and the presence of alkaline phosphatase activity. Strain 5YN7-3 $3^{\mathrm{T}}$ can be differentiated from $K$. granuli $\mathrm{Ko}^{\mathrm{T}} 4^{\mathrm{T}}$ based on the absence of nitrate reduction and starch hydrolysis, and the assimilation of L-alanine and glycogen. Strain $5 \mathrm{YN} 7-3^{\mathrm{T}}$ was also clearly differentiated from $K$. soli $5 \mathrm{YN} 9-8^{\mathrm{T}}$ based on growth in MacConkey agar, assimilation of L-alanine and potassium 5-ketogluconate, and the presence of alkaline phosphatase activity. The fatty acid composition of $5 \mathrm{YN} 7-3^{\mathrm{T}}$ was similar to that of K. granuli Ko04 $4^{\mathrm{T}}$. However, strain 5YN7-3 $3^{\mathrm{T}}$ could be differentiated from K. adipata Chj $404^{\mathrm{T}}$ by a lack of iso- $\mathrm{C}_{11: 0} 3-\mathrm{OH}$.

Based on the data from polyphasic studies including analyses of physiological traits, fatty acid composition, $16 \mathrm{~S}$ rRNA gene sequence and DNA-DNA hybridization, strain 5 YN7-3 ${ }^{\mathrm{T}}$ represents a novel species within the genus Kaistia, for which the name Kaistia terrae sp. nov. is proposed.

\section{Description of Kaistia terrae sp. nov.}

Kaistia terrae (ter'rae. L. gen. n. terrae of the soil).

Cells are Gram-stain-negative, aerobic, non-motile, short rods, $0.8-0.9 \mu \mathrm{m}$ in width and $1.2-1.4 \mu \mathrm{m}$ in length. Cells grow on R2A, NA, TSA and MacConkey agar. Colonies on $\mathrm{R} 2 \mathrm{~A}$ at $30{ }^{\circ} \mathrm{C}$ are ivory-coloured, convex and round with clear margins. Grows at $5-35{ }^{\circ} \mathrm{C}$ (optimum, $30{ }^{\circ} \mathrm{C}$ ), but not at $37{ }^{\circ} \mathrm{C}$. Grows at $\mathrm{pH} 5.0-8.0$ (optimum, 7.0). Able to grow without $\mathrm{NaCl}$ added to the medium and does not tolerate salt levels above $1 \%$. Does not grow anaerobically on R2A. Positive for oxidase and catalase tests. Xanthine is hydrolysed, but casein, chitin, CM-cellulose, DNA, hypoxanthine, pectin, starch, Tween 80 and tyrosine are not hydrolysed. Positive for urease, aesculin hydrolysis and $\beta$-galactosidase, but negative for nitrate reduction, indole production, glucose fermentation, arginine dihydrolase and gelatin hydrolysis (API 20NE test strip). Assimilates D-glucose, L-arabinose, D-mannose, D-mannitol, $N$-acetylglucosamine, maltose, L-rhamnose, D-ribose, inositol, sucrose, glycogen, salicin, melibiose, L-fucose and D-sorbitol, weakly assimilates L-alanine, lactic acid, potassium 5-ketogluconate and potassium 2-ketogluconate, and does not assimilate potassium gluconate, capric acid, adipic acid, malic acid, trisodium citrate, phenylacetic acid, itaconic acid, suberic acid, sodium malonate, sodium acetate,

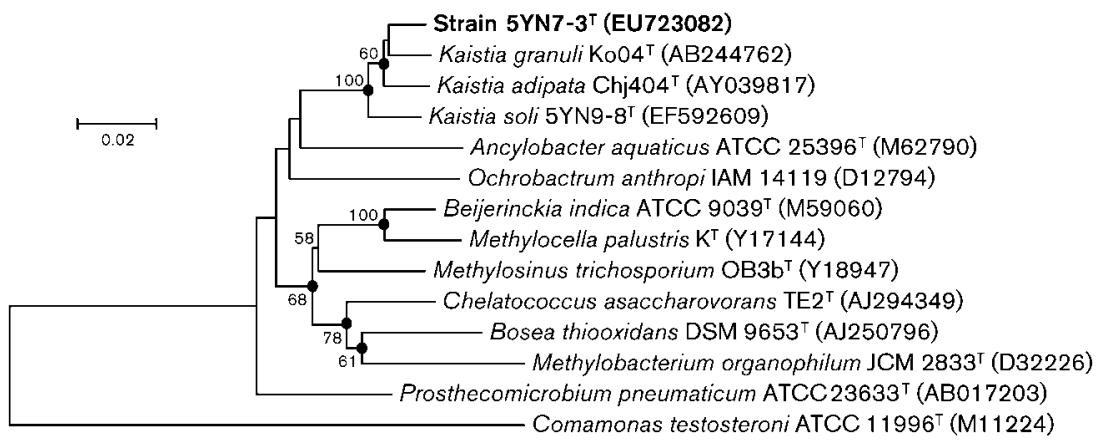

http://ijs.sgmjournals.org
Fig. 1. Neighbour-joining tree based on $16 \mathrm{~S}$ rRNA gene sequences showing the phylogenetic relationships between strain 5 YN7-3 ${ }^{T}$ and closely related species. Filled circles indicate that the corresponding branches were also recovered in the maximum-parsimony tree. Bootstrap values below $50 \%$ are not indicated. Bar, 0.02 changes per nucleotide position. 
3-hydroxybenzoic acid, L-serine, propionic acid, valeric acid, L-histidine, 3-hydroxybutyric acid, 4-hydroxybenzoic acid or L-proline (API 20NE and API ID 32GN test strips). Positive for the following enzyme activities (API ZYM test strip): alkaline phosphatase, esterase (C4), leucine arylamidase, acid phosphatase, naphthol-AS-BI-phosphohydrolase, $\alpha$-glucosidase and $\beta$-glucosidase. Negative for the following enzyme activities: esterase lipase (C8), lipase $(\mathrm{C} 14)$, valine arylamidase, cystine arylamidase, trypsin, $\alpha$-chymotrypsin, $\alpha$-galactosidase, $\beta$-galactosidase, $\beta$-glucuronidase, $N$-acetyl- $\beta$-glucosaminidase, $\alpha$-mannosidase and $\alpha$-fucosidase. Major fatty acids are $\mathrm{C}_{18: 1} \omega 7 c(51.2 \%), \mathrm{C}_{19: 0}$ cyclo $\omega 8 c(25.0 \%), \mathrm{C}_{18: 0}(12.9 \%)$ and $\mathrm{C}_{16: 0}(10.8 \%)$ ( $>10 \%$ of the total fatty acids). Ubiquinone-10 is the predominant quinone. The DNA G $+\mathrm{C}$ content of the type strain is $66.5 \mathrm{~mol} \%$.

The type strain, 5YN7-3 $3^{\mathrm{T}} \quad\left(=\mathrm{KACC} 12910^{\mathrm{T}}=\mathrm{DSM}\right.$ $\left.21341^{\mathrm{T}}\right)$, was isolated from wetland soil of Yongneup, Republic of Korea.

\section{Acknowledgements}

This work was supported by a grant from the National Academy of Agricultural Science, Rural Development Administration of Republic of Korea.

\section{References}

Ausubel, F. M., Brent, R., Kingston, R. E., Moore, D. D., Seidman, J. G., Smith, J. A. \& Struhl, K. (editors) (1987). Current Protocols in Molecular Biology. New York: Wiley.

Chun, J., Lee, J.-H., Jung, Y., Kim, M., Kim, S., Kim, B. K. \& Lim, Y.-W. (2007). EzTaxon: a web-based tool for the identification of prokaryotes based on 16 S ribosomal RNA gene sequences. Int J Syst Evol Microbiol 57, 2259-2261.

Felsenstein, J. (1985). Confidence limits on phylogenies: an approach using the bootstrap. Evolution 39, 783-791.

Fitch, W. M. (1971). Toward defining the course of evolution: minimum change for a specific tree topology. Syst Zool 20, 406-416.

Groth, I., Schumann, P., Weiss, N., Martin, K. \& Rainey, F. A. (1996). Agrococcus jenensis gen. nov., sp. nov., a new genus of actinomycetes with diaminobutyric acid in the cell wall. Int J Syst Bacteriol 46, 234239.

Im, W. T., Yokota, A., Kim, M. K. \& Lee, S. T. (2004). Kaistia adipata gen. nov., sp. nov., a novel $\alpha$-proteobacterium. J Gen Appl Microbiol 50, 249-254.

Kimura, M. (1983). The Neutral Theory of Molecular Evolution. Cambridge: Cambridge University Press.
Kumar, S., Tamura, K. \& Nei, M. (2004). MEGA3: integrated software for molecular evolutionary genetics analysis and sequence alignment. Brief Bioinform 5, 150-163.

Kwon, S. W., Kim, J. S., Park, I. C., Yoon, S. H., Park, D. H., Lim, C. K. \& Go, S. J. (2003). Pseudomonas koreensis sp. nov., Pseudomonas umsongensis sp. nov. and Pseudomonas jinjuensis sp. nov., novel species from farm soils in Korea. Int J Syst Evol Microbiol 53, 21-27.

Kwon, S.-W., Kim, B.-Y., Kim, W.-G., Yoo, K.-H., Yoo, S.-H., Son, J.-A. \& Weon, H.-W. (2008). Paludibacterium yongneupense gen. nov., sp. nov., isolated from a wetland, Yongneup, in Korea. Int J Syst Evol Microbiol 58, 190-194.

Lee, H.-W., Yu, H.-S., Liu, Q.-M., Jung, H.-M., An, D.-S., Im, W.-T., Jin, F.-X. \& Lee, S.-T. (2007). Kaistia granuli sp. nov., isolated from anaerobic granules in an upflow anaerobic sludge blanket reactor. Int J Syst Evol Microbiol 57, 2280-2283.

Mesbah, M., Premachandran, U. \& Whitman, W. B. (1989). Precise measurement of the $\mathrm{G}+\mathrm{C}$ content of deoxyribonucleic acid by highperformance liquid-chromatography. Int J Syst Bacteriol 39, 159-167.

Reasoner, D. J. \& Geldreich, E. E. (1985). A new medium for the enumeration and subculture of bacteria from potable water. Appl Environ Microbiol 49, 1-7.

Saitou, N. \& Nei, M. (1987). The neighbor-joining method: a new method for reconstructing phylogenetic trees. Mol Biol Evol 4, 406425.

Seldin, L. \& Dubnau, D. (1985). Deoxyribonucleic acid homology among Bacillus polymyxa, Bacillus macerans, Bacillus azotofixans, and other nitrogen-fixing Bacillus strains. Int J Syst Bacteriol 35, 151-154.

Smibert, R. M. \& Krieg, N. R. (1994). Phenotypic characterization. In Methods for General and Molecular Bacteriology, pp. 607-654. Edited by P. Gerhardt, R. G. E. Murray, W. A. Wood \& N. R. Krieg. Washington, DC: American Society for Microbiology.

Thompson, J. D., Higgins, D. G. \& Gibson, T. J. (1994). ClusTAL W: improving the sensitivity of progressive multiple sequence alignment through sequence weighting, position-specific gap penalties and weight matrix choice. Nucleic Acids Res 22, 4673-4680.

Wayne, L. G., Brenner, D. J., Colwell, R. R., Grimont, P. A. D., Kandler, O., Krichevsky, M. I., Moore, L. H., Moore, W. E. C., Murray, R. G. E. \& other authors (1987). International Committee on Systematic Bacteriology. Report of the ad hoc committee on reconciliation of approaches to bacterial systematics. Int J Syst Bacteriol 37, 463-464.

Weisburg, W. G., Barns, S. M., Pelletier, D. A. \& Lane, D. J. (1991). $16 \mathrm{~S}$ ribosomal DNA amplification for phylogenetic study. J Bacteriol 173, 697-703.

Weon, H.-Y., Kim, B.-Y., Yoo, S.-H., Kwon, S.-W., Go, S.-J. \& Stackebrandt, E. (2008a). Uliginosibacterium gangwonense gen. nov., sp. nov., isolated from a wetland, Yongneup, in Korea. Int $J$ Syst Evol Microbiol 58, 131-135.

Weon, H.-Y., Lee, C.-M., Hong, S.-B., Kim, B.-Y., Yoo, S.-H., Kwon, S.-W. \& Go, S.-J. (2008b). Kaistia soli sp. nov., isolated from a wetland in Korea. Int J Syst Evol Microbiol 58, 1522-1524. 